\title{
SEISMIC DESIGN OF TIMBER STRUCTURES STUDY GROUP REVIEW, MARCH 1986
}

\author{
R. Williams*
}

\section{BACKGROUND}

Timber structures have had a
reputation for performing comparatively
well in earthquakes However other
structural materials now have design
codes and recommendations that
considerably improve their performance
during earthquake In addition the form
of timber structures has changed
considerably in recent years, typically
with less timber, bigger spans and less
non-structural walls.
recommendations and codes need to be
reviewed and rewrtten to ensure adequate
performance is achieved.

In 1965 New Zealand Standards issued NZS 1900 Chapter 8 , Design Loads. This code of practice set the basic levels of seismic loading to be designed for in New zealand, and while they have been modified and refined, the principles established still exist in our present code (NZS 4203:1984) today. The 1965 code was the first code to make reference to the principle of ductility, the ability of some materials and structures to be deformed briefly beyond their elastic limit without catastrophic failure. The ability to withstand large displacements temporarily permitted design loadings to be used which are considerably lower than would have been the case had the structure been assumed to be brittle and thus been required to remain elastic through any seismic disturbance. A corollary is that non-ductile failure of any member must be suppressed by consideration of the capacity loads on it that can be generated by the yielding mechanism.

\section{STUDY GROUP}

This study group was set up under the cooperative sponsorship of the New Zealand National Society for Earthquake Engineering and the Timber Design Society in 1982 and has since issued 12 newsletters and held almost as many meetings. The study group consists of university and government scientists, government engineers and several private consultants. All members have a specific interest in the design of timber structures.

*Ministry of Works and Development, Hamilton
This review introduces a number of background and state of the art papers (Ref 1-6) which will form the basis of interim recommendations to be published late 1986

\section{OBJECTIVES}

This study group was set up with its stated objectives as follows:

(1) To produce a set of recommendations for the design of timber structures to withstand extreme loadings that occur infrequently such as earthquake and high wind. These recommendations are to be based on the present state of the art and to give guidance to practicing design engineers (consulting, industry, central and local government).

(2) To disseminate the recommendations by way of publication and to provide workshops on these topics.

(3) To make recommendations on future research required to resolve the remaining uncertainties.

Some of the problems addressed by the study group were:

\section{IS EARTHQUAKE LOAD A CRITICAL DESIGN CASE?}

Williams has demonstrated (Ref 7) that for most buildings two storey and greater earthquake loads may well be critical and that for many of the larger single storey buildings earthquake loads may be critical in at least one direction. This study was carried out using existing loading code and timber design codes and confirmed that problem could not be ignored for other than small single storey buildings and that the problem affected all areas in New Zealand.

\section{SHOULD LIMIT STATE DESIGN BE USED} FOR TIMBER?

The study group agrees that if consistent levels of safety are to be achieved for different load cases and with the trend towards probabilistic design then limit state design is the only rational way of separating the material effects from the loading effects. The arguments that this is introducing double design ignore the fact that deflection design is already a 
separate design from working stress design and requires its own load cases. this study group will be recommending suitable limit state strength/stresses for design of critical elements to withstand seismic and wind loads.

\section{CAN WE ACHIEVE DUCTILITY IN TIMBER STRUCTURES?}

Failure of timber in tension and bending must generally be considered to be brittle and must either be protected by capacity design or by high load factors (SM factors, see para. 7).

\section{Conventional ductility} normally achieved by the use of steel yielding in tension and compression or in flexure. In timber structures the latter may be achieved by systems such as the cross bracing with yielding rings described by Tyler (Ref 8) or necked steel gusset plates, Thurston and Flack (Ref 9) (modified nailplates). Investigation into details involving the shanks of nails and bolts in flexure produce hysteresis loops that are both thinner and of a different shape as, in addition to the steel yielding, there is also local compression and crushing of the timber (Ref 9). The loops are pinched in nature rather than elasto-plastic and can better be described as soft-ductile or slackductile. Increasing deflection does have beneficial effects in shifting the period and hence the response but deflections may have to be limited to maintain servicability during moderate earthquakes (Ref 4).

\section{ARE THE SM VALUES FOR TIMBER CORRECT?}

The Loadings code(14) specifie loads for ductile structures which are increased by SM factors for less ductile structures, where $S$ and $M$ are structural type, and Materials factors respectively. For timber it has been the practice to not separate the two factors.

The present code SM values were selected by qualitative rather than quantitative methods. The study group will be proposing new SM factors to the Loading code Liaison Cormittee based on test data and analysis. Further details ae covered by Moss, Carr and Buchanan (Ref 5).

The methods being used by this study group to establish SM factors are:

(1) Carry out dynamic cyclic tests on a range of simple structures to identify hysteretic performance (Ref 10, 11, 12).

(2) Carry out shaking table test a few simple structures with real earthquake records to establish acceptable load deflection characteristics and relate these to design levels (by SM factors) $(\operatorname{Ref} 4)$.

(3) Identify representative hysteresis loops from (1) and (2) for the range of structures being considered and establish suitable computer models to represent these (Ref 1 ).

(4) To apply time history earthquake records to the computer models in (2) and establish acceptable load deflection characteristics and relate these to design levels (by SM factors) (Ref 5 ).

(5) Check sensitivity to different earthquake records and different loop characteristics (Ref 5).

(6) Check (4) against (2).

(7) Recommend SM factors appropriate for the design strength/stresses ratios being recommended (Ref 5).

The current position, March 1986, is that steps 1-5 are well advanced and step 6 is about to commence.

\section{TTMBER DESIGN FOR EARTHQUAKES (EXISTING METHODS)}

other papers form this study group (Refs 1-6) give details of the findings of this study group and any recommendations for future design procedures therefore it is more appropriate here to consider existing methods in order to highlight where and why the changes will be necessary.

8.1 NZS 4203:1984 Code of Practice for General Structural Design and

The lateral load to be applied $\mathrm{V}$ is a function of several factors:

$$
V=C_{d} w_{t}=C \cdot R \cdot S \cdot M \cdot w_{t}
$$

Refer NZS 4203:1984 Cl 3.4 .2

The structural type factor $s$ is a function of the structural performance of the structural system and material factor $M$ and is intended to reflect the performance of the structural type "to dissipate energy in a number of load cycies" and "its degree of redundance where appropriate" (CI 3.4.2). The SM factors are given in Table $5 \mathrm{~B}$ of NZS 4203, reproduced herein as Table 1.

A ductile structure is one that is "capable of deflecting laterally through at least eight load reversals so that the total horizontal deflection is at least four times that at first yield, without the horizontal load carrying capacity of the building being reduced by more than 20 percent" (CI 3.2) (Eig 1).

"A structure having strength greater than that required to meet the design earthquake load $E$ may have less ductile members, but in eight load reversals should be capable of reaching a total lateral deflection of at least four times that when the design earhquake load is applied" (Cl 3.2) (Fig 2).

COMMENT:

The code does not explicitly define "limited ductility" as "less 
Table 1. SM or $S_{P} M_{p}$ factors for timber (from NZS 4203, Table 5B)

\begin{tabular}{|c|c|c|c|}
\hline Item & Description & $\begin{array}{l}\mathrm{SM} \text { or } \\
\mathrm{S}_{\mathrm{p}} \mathrm{M}_{\mathrm{p}}\end{array}$ & $\begin{aligned} C d & =\text { (Assume Zone } A \\
C & =0.15 \text { and } \\
R & =1.0)\end{aligned}$ \\
\hline Bl & $\begin{array}{l}\text { Shear walls or diaphragms: } \\
\text { a Ductile } \\
\text { b Ductile and stiffened with } \\
\text { elastomeric adhesive } \\
\text { c Limited ductility fixed } \\
\\
\text { with elastomeric adhesive }\end{array}$ & $\begin{array}{l}1.0 \\
1.0 \\
1.2\end{array}$ & $\begin{array}{l}0.15 \\
0.15 \\
0.18\end{array}$ \\
\hline B2 & $\begin{array}{l}\text { Moment resisting frames: } \\
\text { a Ductile with an adequate } \\
\text { number of possible plastic } \\
\text { beam hinges } \\
\text { As for item B2(a) but with } \\
\text { connections of limited } \\
\text { ductility }\end{array}$ & $\begin{array}{l}1.2 \\
1.5\end{array}$ & $\begin{array}{l}0.18 \\
0.23\end{array}$ \\
\hline B3 & $\begin{array}{l}\text { Diagonally braced with timber } \\
\text { members capable of acting as } \\
\text { struts or ties: } \\
\text { a With ductile end } \\
\text { b connections } \\
\text { With end connections } \\
\text { having limited ductility }\end{array}$ & $\begin{array}{l}1.7 \\
2.0\end{array}$ & $\begin{array}{l}0.26 \\
0.30\end{array}$ \\
\hline B4 & $\begin{array}{l}\text { Elastically responding } \\
\text { structures }\end{array}$ & 2.4 & 0.36 \\
\hline
\end{tabular}

Table 2. Extract from Table 9, NZS 4203

Seismic force factors for parts and portions of buildings

\begin{tabular}{|c|c|c|c|}
\hline Item & Part or portion & $\begin{array}{l}\text { Direction } \\
\text { of force }\end{array}$ & $c_{p} \max$ \\
\hline 6 & $\begin{array}{l}\text { Floors and roofs acting as } \\
\text { diaphragms and other primary } \\
\text { elements distributing seismic } \\
\text { forces, see c1 } 3.4 .6 .3 \text { : } \\
\text { a Single storey buildings } \\
\quad S_{p} \text { equal to } 1.0 \\
S_{p} \text { equal to } 1.2 \\
S_{p} \text { greater than } 1.2 \\
\text { b Multistorey buildings } \\
\quad s_{p} \text { equal to } 1.0 \\
s_{p} \text { equal to } 1.2 \\
s_{p} \text { greater than } 1.2\end{array}$ & $\begin{array}{l}\text { Any } \\
\text { horizontal }\end{array}$ & $\begin{array}{l}0.2 \\
0.25 \\
0.4 \\
0.3 \\
0.4 \\
0.6\end{array}$ \\
\hline
\end{tabular}




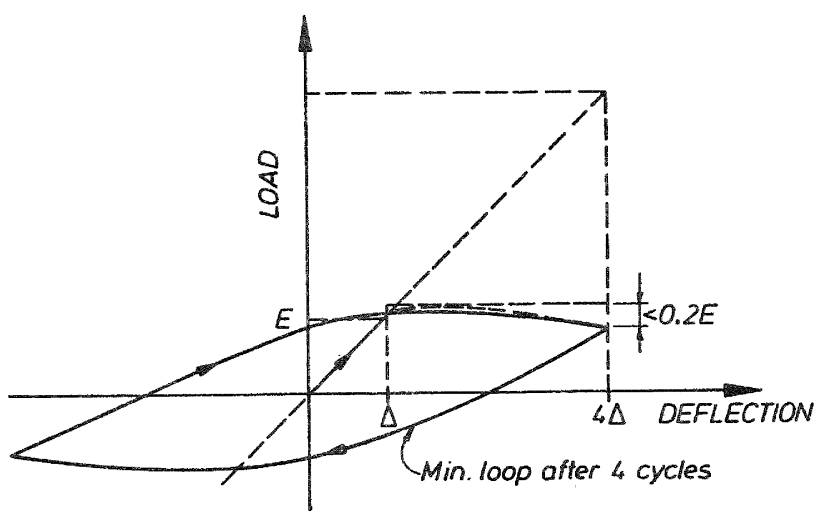

Fig 1 Hysteresis Loop Ductile as Implied by NZS 4203:1984

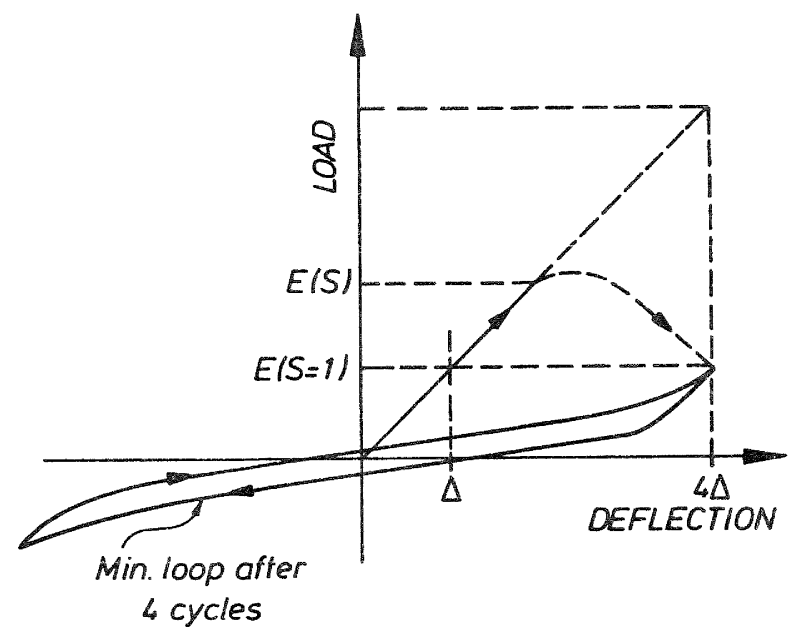

Fig 2 Hysteresis Loop Less Ductile as Implied by NZS 4203:1984

ductile" as above. The code refers to "the design earthquake load $E "$, this is apparently the value $\mathrm{E}$ at $\mathrm{S}=1$, not $\mathrm{S}$ as per table $5 \mathrm{~B}$ but the code does not make this clear or that the residual strength should be at least that requixed if $s=1$.

Elastically responding structures are quoted as having an $\mathrm{SM}=2.4$.

This is out of line with structures of other materials with similarly low levels of viscous damping, eg reinforced concrete with $S=5$, $M=0.08$.

Factors that could be used to justify this are:

EITHER

(1) That high damping is associated with these structures. Comment - It is now known that damping of elastically responding timber structures is very low, $2-5$ percent (Ref 12,13 ) and any contribution from non-structural elements, if present, is very hard to assess.

OR (2) An adjustment to increase design stresses to more appropriate levels for seismic design. Comment - If this is the case it would be far more appropriate to make the adjustment on the stress strength side of the equation rather than reduce the $M$ component in the SM factor.

OR (3) It makes allowance for the inelastic load deflection curve, in that equal displacements can be tolerated at a lower multiple of the design load assuming that the theory of equal deflections applies (Fig 3). Comment structures that are more 1 inearly elastic will require higher SM factors.

OR (4) A combination of the above.

SM factors for elastically (and inelastically) responding strucures will need to be revised to allow for the load deflection characteristics and the low damping.

A further reference to design loadings is in 'parts and portions'. (Table 9, NZS 4203) for design of diaphragms. The relevant material has been extracted and listed in Table 2 .

COMMENT:

This table needs to be revised to cover SM factors for timber structures in the interim. It should be noted that unless timber diaphragms are designed for capacity, ie chords are capable of taking the capacity shear of the sheathing, then the $S_{p}$ will be greater than 1.2 and the higher ${ }^{{ }} C_{p}$ factors should be used.

\subsection{NZS 3603 Code of practice for Timber Design}

Next let us examine NZS 3603:1981. This code refers to NZS 4203 but adds:

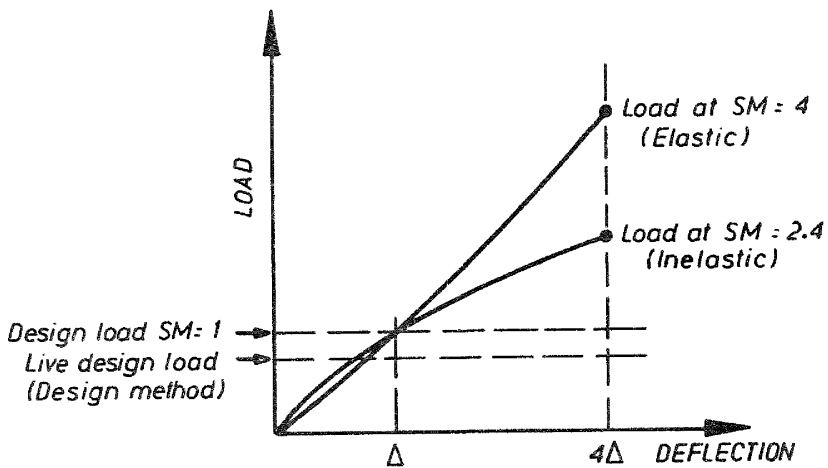

Fig 3 SM Factors for Equal Deflections in Elastic and Inelastic structures 
"2.12.3 Where the alternative method of design is used the permissible stresses in the timber and the permissable loads in the fastenings shall be determined by application of the appropriate modification factors listed in this standard.

2.12.4 The effects of the response of a structure to a level of equivalent seismic load greater than the design load shall be determined by calculating the forces in the structural elements and fastenings:

\section{either}

(a) At the lowest equivalent lateral load to cause an ultimate load in one of the fastening systems of the structure

or

(b) At the equivalent lateral design load incorporating an SM factor of 2.4

whichever is the lesser.

Stress in the timber under this loading condition shall be less than the permissable ultimate stress. The permissible ultimate stress is defined as the basic working stress multiplied by 2.2 .

C2.12.4 The factor 2.2 incorporates the load duration factor and factor of safety."

COMMENT:

Clause 2.12 .3 implies that the alternative design method is suitable but that additional requirements are that either (a) a capacity design approach be used for detailing or (b) that design be equivalent to elastically responding structures.

When ductile behaviour is assumed it is implicit that capacity design is necessary as in 2.12.4 (a) to protect any parts not designed for ductility. It would be desirable to use strength methods but these are not given.

Due to the above problem the only currently available method of designing to 2.12 .4 (a), capacity design, is to design the structure to alternative method loads, select and design the ductile mechanism by normal working stress methods, then calculate the upper bound ultimate strength of the ductile elements and design the remaining elements (which are not required to be ductile) to the forces developed by that mechanism but at lower bound ultimate strengths so they are protected. We are told that we may use $2.2 \mathrm{x}$ basic design stresses for the latter, but are given no advice on upper bound strengths for fasteners and have to estimate them.

$$
\text { In the case } 2.12 .4
$$
elastically responding design loads are used and current practice is to use the alternative method design load equations (with $0.8 \mathrm{E}$ in those equations derived from SM 2.4 values), rather than use strength design "methods.
SUMMARY :

It would be more sensible to use strength design loadings for both capacity design and elastically responding design, but SM values will need to be reappraised and realistic upper and lower bound ultimate strength will have to be given before this is practical. In the meantime alternative design methods have to be used.

\subsection{Analysis}

Stiffness of multipanelled plywood shear walls is mainly a function of shear distortion due to the nail slip around the panels and thus for cases with similar nails and ply thicknesses this can be related to shear area (not moment of inertia as in concrete walls). This simplifies analysis of walls in series as the shear stress will usually become approximately equal in all walls (Fig 4 ).

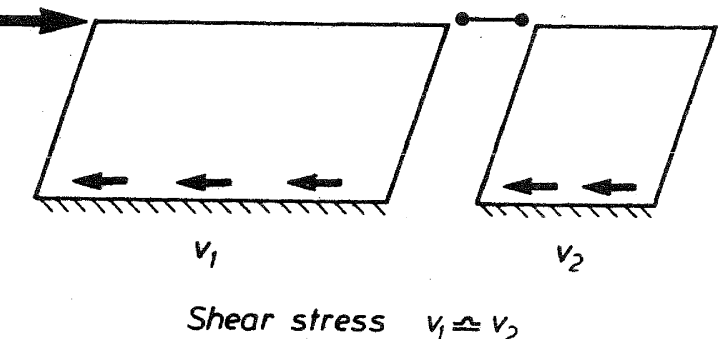

Fig 4 Stress Distributions in Linked Timber Shear walls

Where diaphragms are used consideration has to be given to the relative stiffness of the diaphragms and the walls, eg load distribution of a stiff diaphragm with soft walls such as a large timber diaphragm and short timber shear walls would generate torsion and the loads would be a function of height of walls, shear area and position from centre of rotation whereas a soft diaphragm with stiff walls, as in a timber diaphragm and blockwalls, will act more as a flexible horizontal beam against rigid supports and load will be distributed according to the reaction (Fig 5).

COMMENT:

Designers need to reappraise their analysis procedures from first principles. Designer awareness needs to be improved. "Design of Wood Structures" by Donald E Brieyer gives some guidance.

\subsubsection{Live loads}

-.... Live loads form a significant part of the total load in most timber structures. 


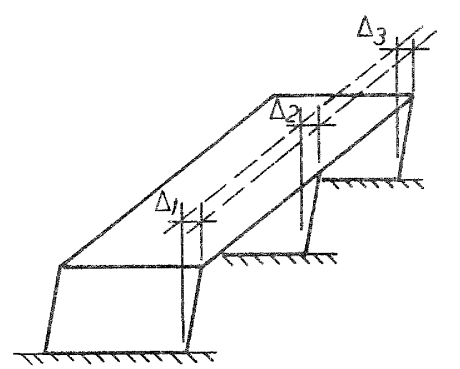

Rigid diaphragm. Soft walls

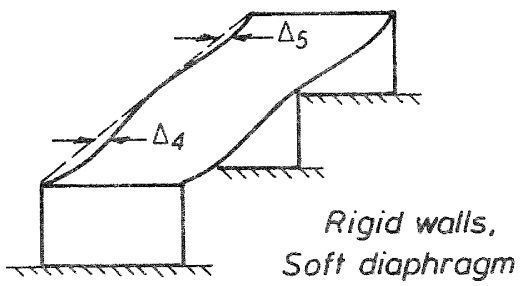

Fig 5 Deflection of Soft and Rigid Diaphragms

Comment:

Study group findings are that live loads do not significantly "baseisolate" by rocking at design load accelerations and should therefore be considered as equivalent dead loads. Surveys of average live loads under New zealand conditions would be useful to check our present assumptions.

\section{3 .2 stresses}

NZS $3603: 1981$ Cl 2.6 Table 3 allows brief load duration stresses to be raised to 1.5 x basic design loads for the alternative method design loads (Eig 6).

\section{$8.3 .3 \mathrm{Nail}$ loads}

There are several references to nail loads both in NZS 3603:1981, Code of practice for Timber Design (15), and NZS 3615:1981 specification for Strength properties and Design Methods for Construction Plywood (Ib). A comparison of the loads for nails into 35 dry timber from these codes is listed in Table 3 .

COMMENT:

Values given in NZS 3603 Table 11 are too conservative for seismic design, NZS 3615 is more useful particularly (Table 16). Where metal side plates are used of sufficient gauge to restrain rotation of the nail slightly higher load than those given in NZS 3615 Table 11 may be used. For capacity design of nailed fastening upper five percentile values will be at least $2 \times$ those shown above.

A load slip curve is given mainly to assist in deflection calculation. It is not intended to imply an ultimate stress or deflection. It can be seen that the design stress is at a slip of $0.9 \mathrm{~mm}$ where as the single nail stress is derived at the lower $1 \frac{0}{5}$ at $0.4 \mathrm{~mm}$ divided

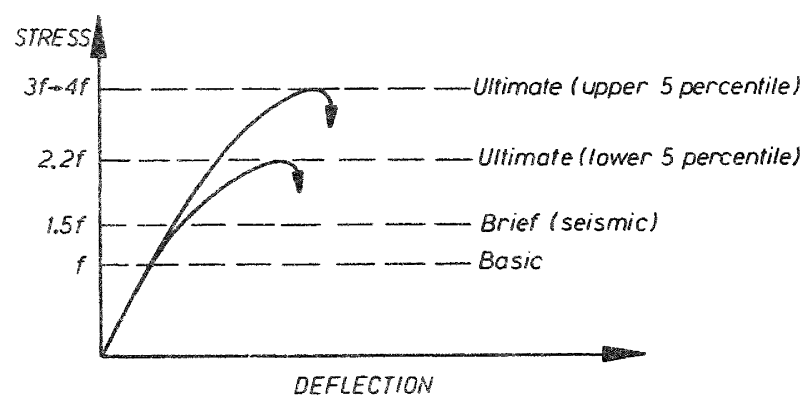

Fig 6 Relative stress Level for Timber to NZS $3603: 1981$

by 1.25 .

To convert these stresses to ultimate lower bound one presumably multiplies by $2.2 / 1.5$ (Eig 6).

\section{CONCLUSIONS}

(1) The present codes do not clearly address strength design for timber and where it does address it, it is usually be scaling basic design stresses. This approach is unsatisfactory.

(2) The SM factors for elastically responding structures may incorrectly incorporate an adjustment for the low design stresses currently being used. Any such adjustment should be removed and transferred to the allowable stress. On the contrary some allowance for the inelastic deflection of some of these structures may permit lowex design loads to be considered for equal displacements.

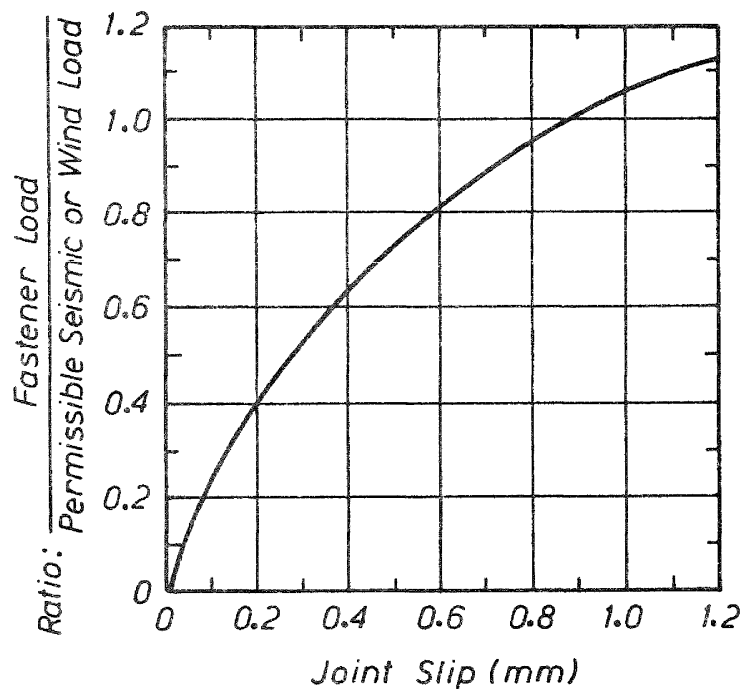

Fig 7 Load-slip curve for Nails or Staples in Plywood or Medium Density Particle Board Diaphragans 
Table 3. Basic nail loads (in Newtons) from NZS $3603^{(15}$ and NZS $3615^{(16)}$

\begin{tabular}{|c|c|c|c|c|c|}
\hline Code & Nail size & $2.5 \mathrm{~mm}$ & $2.8 \mathrm{~mm}$ & $3.15 \mathrm{~mm}$ & Comment \\
\hline \multirow{4}{*}{$\begin{array}{l}\text { NZS } \\
3603\end{array}$} & $\begin{array}{l}\text { Table Il } \\
\text { One nail single } \\
\text { sheax (basic load) }\end{array}$ & 138 & 171 & 214 & \multirow{3}{*}{$\begin{array}{l}\text { Timber to } \\
\text { timber joints. } \\
\text { Based on } \\
1 \text { percentile } \\
0.4 \mathrm{~mm} \text { slip } \\
\text { or strength }\end{array}$} \\
\hline & $\begin{array}{l}\text { Ditto increase for } \\
\text { seismic loads } \\
(x 1.5)\end{array}$ & 207 & 256 & 321 & \\
\hline & $\begin{array}{l}\text { Ditto with metal } \\
\text { side plates } \\
(\times 1.25 \times 1.5)\end{array}$ & 258 & 320 & 401 & \\
\hline & $\begin{array}{l}\text { Table } 28 \\
\text { Seismic loads in } \\
\text { timber ply diagrams }\end{array}$ & 430 & 530 & 650 & $\begin{array}{l}0.9 \mathrm{~mm} \text { joint } \\
\text { slip }\end{array}$ \\
\hline \multirow{3}{*}{$\begin{array}{l}\text { N2S } \\
3615\end{array}$} & $\begin{array}{l}\text { Table } 11 \\
\text { Ply to timber } \\
\text { single shear } \\
\text { (8- nails/joint) }\end{array}$ & 215 & 260 & 325 & \multirow[t]{2}{*}{$\begin{array}{l}\text { Ply to timber } \\
\text { joints. Based } \\
\text { on } 1.5-2.0 \mathrm{~mm} \\
\text { slip strength }\end{array}$} \\
\hline & $\begin{array}{l}\text { Ditto seimsic } \\
\text { loads }(x 1.5)\end{array}$ & 322 & 390 & 487 & \\
\hline & $\begin{array}{l}\text { Table } 16 \\
\text { P1y diaphragm } \\
\text { (blocked) seismic } \\
\text { loads }\end{array}$ & 430 & 530 & 650 & $\begin{array}{l}0.9 \mathrm{~mm} \text { joint } \\
\text { siip }\end{array}$ \\
\hline
\end{tabular}


(3) SM factors should be based on testing and analysis of typical timber structures. The descriptions "ductile" and "limited ductility" should be changed to describe the nature of the hysteresis loops assumed.

(4) The description "Iimited ductility" in Table $5 B$ of NZS 4203 is not adequately defined. The descriptions "soft-ductile" and "slack-ductile" would be more appropriate to timber structures.

(5) Analysis methods need to be more widely explained.

(6) Basic stresses and strengths are derived from a variety of criteria. For strength considerations they need to be strength related and deflections should be considered separately.

\section{REFERENCES}

(1) Dowrick, D J, "Hysteresis loops for timber structures".

(2) Dowrick, D J and Smith, P C, "Timber shear walls for wind and earthquake resistance".

(3) Smith, $\mathrm{P} C$ and Dowrick, D J, "Horizontal timber diaphragms for wind and earthquake resistance".

(4) Deań, J A, Stewart, $W, G$ and Carr, A J, "Seismic behaviour of plywood sheathed shearwalls".

(5) Moss, P J, Carr, A J and Buchanan, A H, "Seismic design loads for low rise buildings".

(6) Collins, $M \mathrm{~J}$, "Design data for nailed joints in shear".

References 1 to 5 are companion papers to the above paper. All papers were presented at the IPENz Conference, February 1986 , and will be published in amended form in:

"Bulletin of the National Society for Earthquake Engineering $1986^{\prime \prime}$ and "The New Zealand Journal of Timber Construction $1986^{\prime \prime}$.

(7) Williams, $\mathrm{R}$ L (1983) "Timber and earthquake engineering", New Zealand Timber Design Society Newsletter No 12 , October 1983.

(8) Tyler, R G (1985) "Further notes on a steel energy absorbing element for braced frameworks" NZNSEE Bulletin, Vol 13, No 3, September 1985, pp $270-279$.

(9) Lowe, P G and Edwards, $M$ R (1984) "Aspects of ductility in nailed timber connections", proceedings or Pacific Timber Engineering Conference, Auckland, May 1984.

(10) Thurston, $S \mathrm{~J}$ and Flack, P F (1979) "Cyclic loading of large timber T joints incorporating steel side plates" "MWD Central Laboratory Report No 5-79/6, Wellington, 1979 .
(11) Thurston, S J (1984) "In-plane cyclic shear tests on ply-sheathed bracing walls, MWD central Laboratories Report No $5-84 / 2$ wellington, 1984 .

(12) Yap, $\mathrm{K} K(1984)$ "An investigation of damping characteristics and seismic response of piy box and nail plate portal frames" MWD Central Laboratories Report No 5-84/12, Wellington, 1984 .

(13) Phillips, $M$ H, wood, $J$ $H$ and Docherty, K (1984) "Horizontal vibration of houses" " MWD Central Laboratories Report No 5-84/3, Wellington, 1983 .

(14) NZS 4203:1984 'Code of practice for General Structural Design and Design Loading for Buildings", SANZ, Wellington, $1984,100 \mathrm{pp}$.

(15) NZS 3603:1981 Code of Practice for Timber Design", SANZ, Wellington, $1981,75 \mathrm{pp}$

(16) NZS 3615:1981 'Specification for Strength properties and Design Methods for Construction Plywoods", SANZ, Wellington, 1981. 